\title{
Connection of Investment Activity and Digitalization in the Megacities of the Republic of Kazakhstan
}

\author{
Lidiya M. Bekenova ${ }^{1 *}$, Valeriy A. Korvyakov ${ }^{1}$, Igor M. Drapkin ${ }^{2}$ \\ ${ }^{1}$ Almaty Academy of Economics and Statistics, Kazakhstan, , Str. Zhandosov 59, 050035, Almaty, \\ Kazakhstan \\ ${ }^{2}$ Ural Federal University; 1Str. Mira 19, 620001, Yekaterniburg, Russia
}

\begin{abstract}
The purpose of the article is to study the influence of digitalization factors on the investment activity of the largest cities of the Republic of Kazakhstan. During the research, the methods of correlation analysis, indexing, comparison, generalization, and synthesis were applied. The scientific novelty of the study lies in assessing the impact of digitalization on the investment potential of cities. The authors selected and analyzed indicators for assessing the level of digitalization of the megalopolises of the Republic of Kazakhstan; the methodology was modified and the level of digitalization of cities of republican significance of the Republic of Kazakhstan was assessed, conclusions were drawn about the current and future potential of digitalization as a factor in increasing the investment attractiveness of these cities. General conclusions were made that for Almaty and Nur-Sultan, digitalization is already a good factor in attracting investment, while Shymkent needs enhanced development of digital infrastructure for it to become a factor in increasing investment activity in the city. The research results can be used both in the formation of long-term plans for the development of these cities, and as a basis for further research in this direction. Prospects for further research on this topic - in increasing the available reliable and relevant data through the collection of official statistics, expanding the range of digitalization factors affecting investment activity and the use of more comprehensive assessment methods that will determine not only the closeness of the relationship, but also the exact value of the effects of factors each other.
\end{abstract}

Keywords: digitalization, investment activity, investment potential, investment attractiveness, megalopolises.

For citation: Bekenova, L.M., Korvyakov, V.A. \& Drapkin, I.M. (2021). Connection of Investment Activity and Digitalization in the Megacities of the Republic of Kazakhstan. Economics: the Strategy and Practice, 16(3), 94-105, https://doi.org/10.51176/1997-9967-2021-3-94-105

* Corresponding author: Lidiya M. Bekenova - PhD in Economic sciences, Associate Professor, Almaty Academy of Economics and Statistics, Kazakhstan, 050035, Almaty, Zhandosov St., 59; e-mail: lida.bekenova@bk.ru

Conflict of interests: the authors declare that there is no conflict of interest

Financial support: The article was prepared within the framework of the grant financing project of the Ministry of Education and Science of the Republic of Kazakhstan "Organizational and economic mechanism of managed urbanization in the post-pandemic period" (IRN AP09260795).

The article received: 21.07 .2021

The article approved for publication: 12.08 .2021

Date of publication: 30.09 .2021 


\title{
Қазақстан Республикасының мегаполистеріндегі инвестициялық қызмет пен цифрландырудың байланысы
}

\author{
Бекенова Л.М. ${ }^{*}$, Корвяков В.А. ${ }^{1}$, Драпкин И.М. ${ }^{2}$ \\ ${ }^{I}$ Алматы экономика және статистика академиясы, Жандосов к., 59, 050035, Алматы к.., \\ Қазақсттан \\ ${ }^{2}$ Орал федералдық университеті, Мир к.., 19, 620001, Екатеринбург қ.., Ресей
}

\section{Түйін}

Мақаланың мақсаты Қазақстан Республикасының ірі қалаларының инвестициялық белсенділігіне цифрландыру факторларының ықпал етуін зерттеу болып табылады. Зерттеу барысында корреляциялық талдау, индекстеу, салыстыру, жалпылау және синтез әдістері қолданылған. Зерттеудің ғылыми жаңалығы қалалардың инвестициялық әлеуетіне цифрландырудың ықпалын бағалауда жатыр. ҚР мегаполистерін цифрландыру деңгейін бағалау үшін авторлармен көрсеткішер іріктеліп, бағаланған; ҚР республикалық маңызы бар қалаларын цифрландыру деңгейін бағалау әдістемесі модификацияланып, бағалау жүргізілген; осы қалалардың инвестициялық тартымдылығын арттыратын фактор ретінде цифрландырудың қазіргі және болашақ әлеуеті туралы қорытындылар жасалған. Алматы мен Нұр-Сұлтан үшін цифрландыру қазірдің өзінде инвестицияларды тартудың жақсы факторы болып табылатындығы, ал Шымкент үшін цифрландыру инвестициялық белсенділікті арттыратын факторға айналуы үшін цифрлық инфрақұрылымды жақсарту қажет екендігі туралы тұжырымдар жасалды. Зерттеу нәтижелері осы қалаларды дамытудың ұзақ мерзімді жоспарларын құру кезінде де, сондай-ақ осы бағыттағы зерттеулердің негізі ретінде де қолданыла алады. Осы тақырып бойынша әрі қарайғы зерттеулердің келешегі - ресми статистиканы жинау арқылы қолда бар сенімді және өзекті деректерді көбейтутіп, инвестициялық қызметке әсер ететін цифрландыру факторларының ауқымын кеңейтуде және тек өзара қарым-қатынас деңгейін ғана емес, сонымен бірге факторлардың бірбіріне ықпал етуінің нақты мәнін анықтауға мүмкіндік беретін анағұрлым кешенді бағалау әдістерін қолдануда жатыр.

Түйін сөздер: цифрландыру, инвестициялық белсенділік, инвестициялық әлеует, инвестициялық тартымдылық, мегаполистер.

Дәйексөз алу үшін: Бекенова Л.М., Корвяков В.А., Драпкин И.М (2021). Қазақстан Республикасының мегаполистеріндегі инвестициялық қызмет пен цифрландырудың байланысы. Экономика: стратегия және практика, 16(3), 94-105, https://doi.org/10.51176/1997-9967-2021-3-94-105

* Хат-хабаршы авторы:Бекенова Лидия Молдабайқызы - корреспондент автор, экономика ғылымдарының кандидаты, доцент, Алматы экономика және статистика академиясы, Қазақстан Республикасы, 050035, Алматы қ. Жандосов көш., 59, e-mail: lida.bekenova@bk.ru.

Мүдделер қақтығысы: авторлар мүдделер қақтығысының жоқтығын мәлімдейді.

Қаржыландыру. Мақала ҚР Білім және ғылым министрлігінің «пандемиядан кейінгі кезеңде басқарылатын урбандалудың ұйымдастыру-экономикалық тетігі» гранттық қаржыландыру жобасы шеңберінде әзірленді (ЖTH AP09260795).

Мақала редакцияға түсті: 21.07 .2021

Жариялау туралы шешім қабылданды: 12.08 .2021

Жарияланды: 30.09 .2021 


\title{
Связь инвестиционной активности и цифровизации в мегаполисах Республики Казахстан
}

\author{
Бекенова Л.М. ${ }^{*}$, Корвяков В.А. ${ }^{1}$, Драпкин И.М. ${ }^{2}$ \\ ${ }^{1}$ Алматинская академия экономики и статистики, Республика Казахстан, ул. Жандосова, 59, \\ 050035 , г. Алматы, Казахстан \\ Уральский федеральный университет, ул. Мира, 19, \\ 620001, г. Екатеринбург,Россия
}

\begin{abstract}
Аннотация
Целью статьи является исследование влияния факторов цифровизации на инвестиционную активность крупнейших городов Республики Казахстан - Алматы, Нур-Султане и Шымкенте. Выбор городов обусловлен тем, что данные мегаполисы сосредоточивают значительные человеческие, трудовые, промышленные, инвестиционные ресурсы и являются крупнейшими центрами социально-экономического развития как для своего региона, так и для страны в целом. В процессе исследования применены методы корреляционного анализа, индексирования, сравнения, обобщения и синтеза. Научная новизна исследования заключается в оценке влияния цифровизации на инвестиционный потенциал городов. Авторами отобраны и проанализированы показатели для оценки уровня цифровизации мегаполисов РК; модифицирована методика и проведена оценка уровня цифровизации городов республиканского значения РК, сделаны выводы о текущем и будущем потенциале цифровизации как фактора повышения инвестиционной привлекательности этих городов. Сделаны общие выводы, что для Алматы и Нур-Султана цифровизация уже является хорошим фактором привлечения инвестиций, в то время как Шымкенту необходимо усиленное развитие цифровой инфраструктуры, чтобы она стала фактором повышения инвестиционной активности в городе. Результаты исследования могут быть использованы как при формировании долгосрочных планов развития этих городов, так и в качестве основы для дальнейших исследований в этом направлении. Перспективы дальнейшего исследования этой темы - в увеличении доступных достоверных и релевантных данных за счёт сбора официальной статистики, расширении состава факторов цифровизации, влияющих на инвестиционную активность и применении более комплексных методов оценки, которые позволят определить не только тесноту взаимосвязи, но и точное значение частных эффектов факторов друг на друга.
\end{abstract}

Ключевые слова: цифровизация, инвестиционная активность, инвестиционный потенциал, инвестиционная привлекательность, мегаполисы.

Для цитирования: Бекенова Л.М., Корвяков В.А., Драпкин И.М. (2021). Связь инвестиционной активности и цифровизации в мегаполисах Республики Казахстан. Экономика: стратегия и практика, 16(3), 94-105, https:// doi.org/10.51176/1997-9967-2021-3-94-105

* Корреспондирующий автор: Бекенова Лидия Молдабаевна - кандидат экономических наук, ассоциированный профессор, Алматинская академия экономики и статистики, Республика Казахстан, 050035, г. Алматы, ул. Жандосова, 59, e-mail: lida.bekenova@,bk.ru.

Конфликт интересов: авторы заявляют об отсутствии конфликта интересов.

Финансирование. Статья подготовлена в рамках проекта грантового финансирования Министерства образования и науки РК «Организационно-экономический механизм управляемой урбанизации в постпандемийный период» (ИРН АР09260795).

Статья поступила в редакцию: 21.07 .2021

Принято решение о публикации: 12.08 .2021

Опубликовано: 30.09 .2021 


\section{Введение}

Усиление инвестиционной активности, инвестиционного потенциала региона или города - одна из главных целей управления в условиях рыночной экономики в принципе, поскольку именно инвестиции создают возможности для устойчивого экономического роста, усиления инновационной активности и повышения качества жизни населения. Следовательно, вопросы привлечения инвестиций играют большую роль в любые программы долгосрочного экономического развития. Ничего удивительного, таким образом, нет в том, что исследователи регулярно проводят исследования о том, какие факторы могут оказать положительное влияние на инвестиционную активность и потенциал региона или города в настоящий момент или в ближайшем будущем, исходя из современного же социально-экономического и технологического контекста.

В свою очередь, цифровизация - один из самых масштабных, долгоиграющих и влиятельных трендов современности - не могла не оказаться в фокусе исследований о возможных факторах развития инвестиционной активности. Более того, цифровизация просто не могла не попасть в фокус внимания - информационные технологии сегодня внедряются практически во все сферы человеческой жизни и оказывают на них бесспорно заметное влияние.

В этом контексте города, а особенно города-мегаполисы, в которых представлены практически все возможные виды экономической активности, которые, к тому же, тесно связаны с не менее разнообразными социальными, культурными, технологическими процессами, являются почти идеальными объектами для изучения возможной взаимосвязи между цифровизацией и инвестиционной активностью.

В рамках данной работы изучены возможные взаимосвязи между факторами цифровизации и инвестиционной активностью в трёх крупнейших городах Республики Казахстан: Алматы, Нур-Султане и Шымкенте, единственных городах с населением более чем миллион человек. Выбор городов обусловлен тем, что данные мегаполисы сосредоточивают значительные человеческие, трудовые, промышленные, инвестиционные ресурсы и являются крупнейшими центрами социально-экономического развития как для своего региона, так и для страны в целом.

В ходе исследования авторы столкнулись со сложностями, связанными преимущественно с недостатком данных или их недостаточной протяжённостью во времени, и выражают надежду, что в ближайшем будущем - в течение 4-6 лет - можно будет повторить исследование на более обширных данных с применением более совершенного инструментария.

\section{Литературный обзор}

Существует множество работ, изучающих влияние цифровизации на развитие различных экономических секторов или показателей. Нет ничего удивительного в том, что можно найти много публикаций, изучающих взаимосвязь между цифровизацией и инвестиционной активностью. В первую очередь, необходимо найти консенсус относительно того, что считать цифровизацией и инвестиционной активностью.

K примеру, Ачаповская М. определяет цифровизацию как «современный инновационный этап экономического развития, в основе которого лежит интеграция физических и цифровых ресурсов в сфере производства и потребления, в экономике и в обществе» [1].

Блумберг Дж. в своей статье утверждает, что для цифровизации до сих пор нет чёткого определения и приводит несколько вариантов: «Цифровизация - способ, которым многие аспекты социальной жизни реструктурируются вокруг цифровых коммуникаций и медиа», «Цифровизация - это использование цифровых технологий для изменения бизнесмоделей и создания новых возможностей для получения доходов и генерирования ценности» [2].

Согласно библиографическому обзору по теме цифровизации, проведённому Парида В. и др., большая часть авторов апеллирует к цифровизации как пути создания новых бизнес-моделей с помощью цифровых технологий. Новые бизнес-модели со временем становятся более привлекательными для инвесторов [3].

Бреннен Дж. и Крайсс Д. утверждают, что дискуссии о цифровизации нередко включают обсуждение информации как основы для определения цифровизации, а значит, наибольшее значение в цифровизации имеют компьютеры и интернет, значительно изменившие существующие парадигмы социально-экономической жизни [4].

Что касается инвестиционной активности, то здесь также существует множество интерпретаций. Так, Хашимова Н. и Хусаинова Дж. считают, что основной инновационной активности является инвестиционный потенциал - поступающие в регион ресурсы и эффективность их использования, которая 
и определяет инвестиционную активность в дальнейшем [5].

Олейник Е. и Захарова А. оценили основные факторы инновационной активности и пришли к выводу, что объём инвестиций, а вместе с ним и инвестиционная активность в виде инвестиционных потоков определяется множеством факторов, в числе которых также и развитие ИКТ [6].

В последнее время наблюдается усиление научного и практического интереса к вопросам управления городским развитием в условиях пандемии [7,8]. Глобальный директор Всемирного банка по практикам городского управления Вахба С. и мэр города Хельсинки Вапаавуори Я. изложили свое видение концепции функционального города и о том как он справляется с пандемией коронавирусной инфекции, в совместной статье [9]. Авторы утверждают, что процессы урбанизации не прекратятся из-за кризиса, города будут продолжать притягивать к себе инновации и людей, творчество и капитал. По их мнению, цифровизация предложит решения, которые сделают глобальное сообщество городов еще более взаимосвязанными.

Относительно методов оценки инвестиционного потенциала и активности, через призму факторов цифровизации, также можно выделить ряд научных работ.

Квашнина Д. и Ершова И. проанализировали методы оценки развития инновационноинвестиционного потенциала регионов на основе анализа исследований других авторов [10]. Одним из основных выводов их исследования можно считать утверждение, что применение интегральных показателей для оценки потенциала является распространенным методом. Кроме того, важно при оценке уделять внимание интеллектуальным ресурсам.

Листопад М. и Пшул Л. проанализировали инвестиционную привлекательность в условиях цифровизации на примере строительной отрасли РФ. Основной метод - расчёт долей цифровых и инвестиционных показателей в ВВП и последующим сравнительным анализом таких же долей у развитых стран [11].

Булавко О. и др. в своём исследовании определили показатели, факторы и критерии эффективного развития инвестиционного потенциала в условиях цифровизации и реализации концепции «Индустрия 4.0». Авторы подчёркивают важность цифровизации в повышении инвестиционной привлекательности реального сектора глобальной экономики [12].
Коллектив авторов из России и Европы опубликовал монографию «Методология развития экономики, промышленности и сферы услуг в условиях цифровизации», в которой они анализируют, делают выводы и дают рекомендации, связанные с экономическим развитием в условиях цифровизации. Полное описание труда нерелевантно для данной работы, однако отметим, что значимыми для настоящего исследования можно назвать выводы авторов главы 2 «Развитие региональной и отраслевой экономики в условиях цифровизации», подчёркивающих важность цифровизации и инновационного развития для экономического развития регионов [13].

Тем не менее, подобный анализ для казахстанских городов практически не проводился, в публикациях за последние пять лет замечены следующие работы.

Исследование Алибековой Г. и др. направлено на анализ цифровых показателей Казахстана посредством данных национальной статистики и международных индексов, таких как Глобальный индекс инноваций и Индекс развития ИКТ [14].

Панзабекова А. и др. рассмотрели цифровизацию как потенциал для развития качества жизни населения, и на основе адаптированной инвариантной методике расчета провели анализ цифрового качества жизни населения Казахстана и его регионов [15].

Жумашева С., Муханова А., Смагулова Ж. провели исследование о возможностях цифровизации как основы для развития инновационно-инвестиционного аграрного сектора экономики РК [16]. Основным методом исследования была описательная статистика, и авторы пришли к выводу, что цифровизация повышает инвестиционный потенциал.

Джуманова Р. изучила текущее состояние и тенденции развития инвестиционного климата в РК в условиях цифровизации [17]. Один из основных выводов автора заключается в том, что именно цифровизация казахстанской экономики должна привести к увеличению потоков прямых иностранных инвестиций в приоритетные для долгосрочного устойчивого развития страны отрасли.

Нуркатов А. в своей работе рассмотрел особенности развития регионов РК с тем, чтобы выделить основные пути преодоления региональных различий в экономическом развитии [18]. Главным выводом автора можно считать утверждение о необходимости повышения качества информационно-телекоммуникационной инфраструктуры для повы- 
шения экономической привлекательности регионов и увеличения объемов инвестиций.

Моисеева Т. утверждает, что уровень развития цифровой экономики улучшает условия ведения предпринимательской деятельности, а значит и инвестиционную привлекательность страны, иллюстрируя свои тезисы данными по странам ЕАЭС [19].

Bce авторы, с некоторыми некритичными различиями, сходятся в том, что цифровизация - это процесс внедрения цифровых технологий в общественноэкономические процессы, а инвестиционный потенциал лучше всего оценивать по совокупности экономических показателей, характеризующих основные социальноэкономические процессы. Какие конкретно показатели характеризуют эти процессы зависит от автора, поэтому их выбор мы оставили за собой, как и дискуссию об этом выборе.

В целом, исходя из анализа источников можно сделать вывод о высокой важности определения силы и качества взаимосвязей между цифровизацией и инвестиционной привлекательностью, и для достижения этих целей вполне адекватным методом является интегральная оценка с учётом особенностей регионального развития.

\section{Методология}

В основу методологии исследования положен подход Е.Киселевой, суть которого заключается в расчёте интегральных индексов оценки влияния цифровизации на инвестиционную активность города [20]. Для ранжирования российских городов по уровню инвестиционного потенциала и оценки влияния цифровизации на инвестиционную активность исследователем были учтены цифровые факторы, сгруппированные по трем ключевым направлениям: информационно-коммуникационная инфраструктура, цифровое правительство и электронный бизнес. Предложенная Е. Киселевой мето- дика оценки цифрового потенциала территориальных образований позволяет использовать корреляционный анализ для обоснования влияния отобранных статистических показателей, учитываемых в составе потенциала, на уровень инвестиций в основной капитал.

На первом этапе отбираются показатели цифровизации города, которые потенциально могут повлиять на инвестиционную активность за период 2013-2019 гг. Выбор периода обусловлен двумя соображениями: доступностью данных за период, и единообразием методологии сбора данных за период, т.к. методология сбора многих показателей была пересмотрена именно в 2013 г.

На втором этапе методом корреляционного анализа оценивается взаимосвязь между показателями цифровизации и инвестиционной активности, в частности, объемом инвестиций в основной капитал. Отбираются только те показатели, коэффициент корреляции которых выше хотя бы 0,5 (средняя интенсивность связи).

На третьем этапе отобранные показатели цифровизации стандартизируются и интегрируются в общую оценку цифровизации города, влияющей на инвестиционную активность. Стандартизация осуществляется через пересчёт показателя на душу населения (если возможно) и сравнение с пересчитанным показателем по РК, взятым за 1. Интегрирование оценок происходит с помощью расчёта средней арифметической всех оценок по городу. Такая оценка позволяет понять, насколько цифровизация отдельного мегаполиса превосходит среднюю цифровизацию по РК, а значит, создает лучший потенциал для привлечения инвестиций.

Для оценки были использованы данные, взятые с официального сайта Бюро национальной статистики Агентства по стратегическому планированию и реформам Республики Казахстан. Список показателей для расчёта индексов и интегральных оценок для цифровизации приведён в таблице 1.

Таблица 1 - Индикаторы, использованные для расчёта индексов и интегральных оценок цифровизации

Table 1 - Indicators used to calculate indices and integral assessments of digitalization

\begin{tabular}{|l|c|c|}
\hline \multicolumn{1}{|c|}{ Индикаторы цифровизации } & Ед. измерения & Пересчитанный индикатор \\
\hline Число абонентов фиксированного интернета & Тыс. единиц & Единицы на душу населения \\
\hline Доля пользователей сети Интернет 16-74 лет & $\%$ & $\%$ \\
\hline Количество компьютеров в организации & Единицы & Единицы на душу населения \\
\hline Количество организаций использующих сеть интернет & Единицы & Единицы на душу населения \\
\hline Количество компьютеров, подключенных к сети интернет & Единицы & Единицы на душу населения \\
\hline $\begin{array}{l}\text { Количество организаций с автоматизированными бизнес- } \\
\text { процессами }\end{array}$ & Единицы & Единицы на душу населения \\
\hline Примечание-Составлено по источнику [21]
\end{tabular}

Примечание - Составлено по источнику [21]. 
Некоторые показатели были отсеяны ввиду низкого коэффициента корреляции с объемом инвестиций. Кроме того, часть показателей официальной статистики, которые могли бы стать очевидно полезными для анализа, оказалось невозможно использовать из-за слишком малого объема данных.

\section{Результаты}

Расчёт коэффициентов корреляции для факторов цифровизации и объема инвестиции показывают, что для Алматы и Нур-Султана они уже являются достоверно и сильно связанными с инвестиционной активностью, в то время как для Шымкента коэффициенты меньше, что можно интерпретировать как нереализованный потенциал цифровизации для развития инвестиционной активности в городе (таблица 2).

Таблица 2 - Коэффициенты корреляции для факторов цифровизации и объема инвестиций в мегаполисах Казахстана

Table 2 - Correlation coefficients for digitalization factors and investment volume in the megalopolises of Kazakhstan

\begin{tabular}{|c|c|c|c|c|c|c|}
\hline Город & 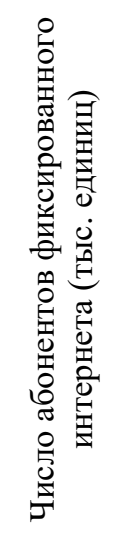 & 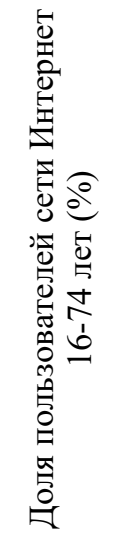 & 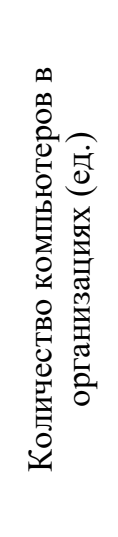 & 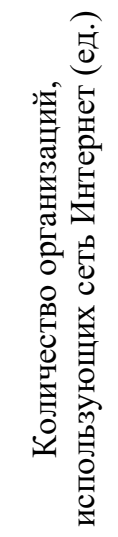 & 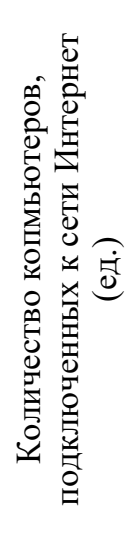 & 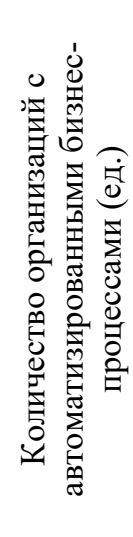 \\
\hline PK & 0,7651 & 0,8680 & 0,9853 & 0,9745 & 0,9752 & 0,6195 \\
\hline Алматы & 0,6471 & 0,8525 & 0,6608 & 0,8710 & 0,8366 & 0,7963 \\
\hline Нур-Султан & 0,7894 & 0,8978 & 0,7803 & 0,7986 & 0,8369 & 0,8289 \\
\hline Шымкент & 0,6426 & 0,5264 & 0,7440 & 0,7302 & 0,6308 & 0,7972 \\
\hline
\end{tabular}

Примечание - Рассчитано авторами по данным [21]..

Результаты расчёта цифровых индексов развития инвестиционного потенциала мегаполисов Казахстана показывают, что НурСултан и Алматы обладают показателями, более чем вдвое превышающими средние по республике, в то время как для Шымкента эти показатели всё ещё заметно ниже (таблица 3).

Исходя из данных, представленных в таблице можно сделать вывод, что до сих пор существует значительное неравенство по основным показателям цифровизации между Алматы и Нур-Султаном, и республикой в целом. Эти два города лучше обеспечены цифровыми технологиями. В то же время Шымкент демонстрирует значительное отставание по этим показателям от средних по республике. Это неравенство постепенно сокращается, что означает постепенное выравнивание показателей в среднем по республике. 
Таблица 3 - Значения цифровых индексов развития инвестиционного потенциала мегаполисов и Казахстана в целом (для сравнения)

Table 3 - Values of digital indices for the development of the investment potential of megalopolises and Kazakhstan as a whole (for comparison)

\begin{tabular}{|c|c|c|c|c|}
\hline Индекс & & Год & & Изменение \\
\hline Охват фиксированным Интернетом абонентов: & 2017 г. & 2018 г. & 2019 г. & \\
\hline Республика Казахстан & 1,000 & 1,000 & 1,000 & - \\
\hline Алматы & 3,902 & 1,652 & 1,585 & $-59,37$ \\
\hline Нур-Султан & 1,222 & 1,727 & 1,785 & $+46,08$ \\
\hline Шымкент & 0,493 & 0,552 & 0,534 & $+8,41$ \\
\hline Доля пользователей сети интернет: & & & & \\
\hline Республика Казахстан & 1,000 & 1,000 & 1,000 & - \\
\hline Алматы & 1,069 & 1,052 & 1,033 & $-3,30$ \\
\hline Нур-Султан & 1,106 & 1,080 & 1,066 & $-3,59$ \\
\hline Шымкент & 1,026 & 1,008 & 0,975 & $-4,99$ \\
\hline Обеспеченность организаций компьютерами: & & & & \\
\hline Республика Казахстан & 1,000 & 1,000 & 1,000 & - \\
\hline Алматы & 2,487 & 2,272 & 2,431 & $-2,25$ \\
\hline Нур-Султан & 2,573 & 2,868 & 2,591 & $+0,71$ \\
\hline Шымкент & 0,604 & 0,672 & 0,591 & $-2,22$ \\
\hline Обеспеченность организаций Интернетом: & & & & \\
\hline Республика Казахстан & 1,000 & 1,000 & 1,000 & - \\
\hline Алматы & 2,754 & 2,421 & 2,468 & $-10,38$ \\
\hline Нур-Султан & 2,365 & 3,749 & 3,580 & $+51,39$ \\
\hline Шымкент & 0,693 & 0,973 & 0,834 & $+20,43$ \\
\hline Подключение компьютеров к Интернету: & & & & \\
\hline Республика Казахстан & 1,000 & 1,000 & 1,000 & - \\
\hline Алматы & 2,768 & 2,512 & 2,636 & $-4,77$ \\
\hline Нур-Султан & 2,548 & 3,052 & 2,615 & $+2,64$ \\
\hline Шымкент & 0,614 & 0,627 & 0,562 & $-8,34$ \\
\hline Автоматизация бизнес-процессов компаний: & & & & \\
\hline Республика Казахстан & 1,000 & 1,000 & 1,000 & - \\
\hline Алматы & 3,253 & 3,174 & 4,687 & $+44,07$ \\
\hline Нур-Султан & 2,095 & 4,441 & 2,026 & $-3,33$ \\
\hline Шымкент & 0,608 & 0,860 & 0,508 & $-16,43$ \\
\hline
\end{tabular}

Примечание - Рассчитано авторами по данным [21]..

Рассмотрим более подробно каждый из индексов:

1. Охват фиксированным Интернетом абонентов. Наиболее значимым наблюдением здесь является переход лидерства от Алматы в 2017 г. к Нур-Султану в 2019 г. Можно однозначно утверждать, что ещё четыре года назад Алматы был безоговорочным лидером по показателю охвата фиксированным интернетом абонентов, в то время как уже в 2019 г. остальные города и регионы республики значительно сократили отставание, а город
Нур-Султан вышел на первое место. Шымкент, в то же время, достигает примерно половины среднего по республике значения.

2. Доля пользователей сети интернет. Данный показатель для мегаполисов колеблется значительно меньше, и отклонение всех трёх от среднего для республики значения можно назвать незначимым. Динамика этого и предыдущего показателя говорят о том, что изменилась структура «потребления» Интернета: если раньше на одного абонента приходилось больше людей, то теперь 


\section{INNOVATION, INNOVATION AND TECHNOLOGICAL DEVELOPMENT, DIGITALIZATION}

практически каждый человек - это отдельный абонент.

3. Обеспеченность организаций компьютерами. Лидером по данному параметру является Нур-Султан, однако Алматы ненамного отстает от него. Оба города примерно в 2,5 раза превышают показатель по Казахстану в целом. Шымкент также достигает чуть более чем половины среднего для республики значения.

4. Обеспеченность организаций Интернетом. Нур-Султан лидирует с большим отрывом от РК и Алматы, более чем в 3,5 раза превышая среднереспубликанский параметр.
5. Подключение

компьютеров к Интернету. И Алматы и Нур-Султан демонстрируют примерно одинаковый отрыв от показателя РК, в то время как Шымкент достигает более чем половины.

6. Автоматизация бизнес-процессов компаний. По параметру автоматизации бизнеспроцессов Алматы лидирует весь наблюдаемый период, однако Нур-Султан тоже превышает средний по РК показатель. Шымкент, как и по прочим индексам, достигает чуть более чем половины значения республики.

Результаты интегрирования индексов в общие оценки по мегаполисам приведены на рисунке 1.

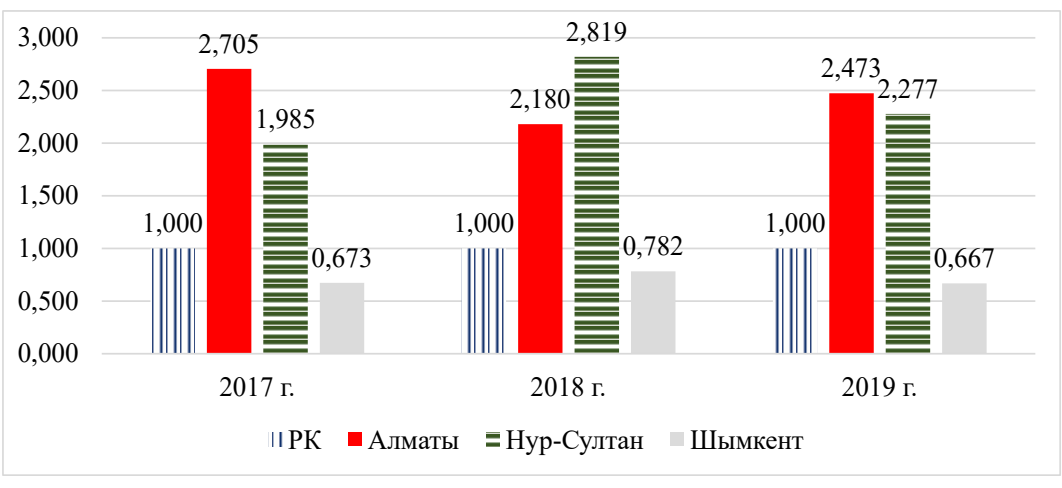

Рисунок 1 - Интегральные оценки мегаполисов РК

Figure 1 - Integral assessments of megalopolises of the Republic of Kazakhstan

Примечание - Рассчитано авторами по результатам данных таблицы 3.

Из представленных на рисунке данных видно, что из трёх мегаполисов у двух (Алматы и Нур-Султан) показатели цифровизации значительно превышают средние по республике значения. Интегральный цифровой показатель развития инвестиционного потенциала города Алматы в 2019 году составляет 2,473, что свидетельствует о более сильных его позициях в сравнении с г. Нур-Султан и г. Шымкент. Наименьший интегральный показатель имеет Шымкент, что связано с низкой долей пользователей сети интернет, недостаточной обеспеченностью организаций компьютерами и автоматизацией бизнеспроцессов компаний.

Одним из важных факторов, на который следует акцентировать особое внимание для развития цифровизации в городах является усиленное развитие цифровой инфраструктуры. Взятый курс Казахстаном на цифровизацию уже по умолчанию предполагает достижение высокого уровня информатизации и автоматизации путем активного использования аппаратных средств, программного обеспечения, телекоммуникаций. Дальнейшие меры по развитию цифровой инфраструктуры предполагают построение новых моделей ведения бизнеса, формирование доверия к надежности и безопасности цифровой инфраструктуры, осуществление периодичной оценки рисков и т.д. Перечисленные меры могут осущестляться частным сектором, а государство в свою очередь может создавать прямые и косвенные стимулы для развития цифровой инфраструктуры. В частности, оно может законодательно закрепить такие условия, согласно которым несколько операторов могут использовать совместной инфраструктуру ИКТ, не создавая собственную. Такая мера позволит усилить конкуренцию между операторами, тем самым улучшить качество 
соединения и ценовую доступность интернета, что в последствии приведет к повышению уровня распространенности интернета в городах. Реализация предложенных мер повысит уровень цифровизации экономик городов, а вместе с тем и их инвестиционную активность.

\section{Выводы}

Результаты исследования позволяют сделать вывод, что цифровизация действительно может выступать как фактор развития инвестиционной активности, привлекательности и потенциала. Более того, весьма вероятно, что цифровизация и инвестиционные процессы поддерживают друг друга: цифровизация повышает инвестиционную активность и привлекательность, а их повышение, в свою очередь, увеличивает приток ресурсов в цифровизацию. Мы предполагаем, что эти взаимосвязи имеет смысл проанализировать с помощью регрессионных моделей, в частности, использующих системы одновременных уравнений. На данный момент применение этого метода затруднено недостаточным количеством данных, поскольку официальные казахстанские структуры начали сбор статистики по цифровизации с 2017-2018 гг.

В рамках данной работы была определена только теснота взаимосвязей, однако расчёт силы частных эффектов влияния каждого из факторов на инвестиционную активность ещё предстоит сделать, когда будет накоплен достаточный объём достоверных статистических данных. Предположительно первый такой анализ можно будет провести через 4-5 лет, например, в рамках систематич еской оценки результатов реализации государственных программ в этих сферах до 2025 г. Важное значение для управления процессом развития цифровизации имеет объективный и своевременный статистический мониторинг процессов и результатов цифровой трансформации в Казахстане.

Исходя из проведенного исследования можно сделать вывод, что Алматы и НурСултан по оценкам цифровизации значительно превышают средние значения по республике, а значит, цифровизация в этих городах уже создала высокий для Казахстана потенциал привлечения инвестиций. Шымкент, в свою очередь, демонстрирует значительно более низкие, чем в среднем по республике, показатели. Можно с уверенностью утверждать, что такой разрыв обусловлен именно неразвитостью цифровизации по анализируемым факторам, поскольку влияние численности населения было исключено в ходе стандартизации. При этом именно потенциал цифровизации как фактора привлечения инвестиций выше именно у Шымкента - развитие цифровой инфраструктуры и сервисов хотя бы до среднего по Казахстану уровня вероятнее всего даст намного больший эффект, чем такое же развитие в Алматы и Нур-Султане, где цифровизация уже является заметным фактором инвестиционного развития.

Для развития цифровизации в городах необходимо акцентировать внимание на создание цифровой инфраструктуры. Цифровизация позволит не только решать внутренние проблемы казахстанских городов, предотвращая потенциальные угрозы, но и внедрять инновации в городскую среду, повышая тем самым инвестиционный потенциал городов.

\section{Список использованных источников}

1. Ачаповская М. (2019). Цифровизация экономики как драйвер экономического развития. Банковский вестник, 3, 52-58.

2. Bloomberg J. (2018). Digitization, digitalization, and digital transformation: confuse them at your peril. [Electronic source]. URL: Retrieved on August 28, 2019 from https://www.forbes.com/sites/ jasonbloomberg/2018/04/29/digitization-digitalizationand-digital-transformation-confuse-them-at-yourperil/\#78e677fd2f2c. (date of access 20.05.2021).

3. Parida V., Sjödin D., Reim W. (2019) Reviewing literature on digitalization, business model innovation, and sustainable industry: Past achievements and future promises // Sustainability, 11(2), 18.

4. Brennen J. S., Kreiss D. (2016). Digitalization //The international encyclopedia of communication theory and philosophy, 1-11.

5. Khashimova N., Khusanjanova J. (2016) Generation of investment potential. Voice of Research, 5, 1, 46-48.

6. Oleinik E., Zakharova A. (2016). Evaluation of the Major Factors of the Region's Investment Activity. Indian Journal of Science and Technology, 9, 36. 1-7.

7. Комаров В. Кризис и пандемия COVID-19 как окно возможностей для гуманизации градостроительной политики. Мониторинг экономической ситуации в России: тенденции и вызовы социально-экономического развития, 2020, 8(110), 7-17.

8. Курочкин А.В. (2020) Стратегическое планирование и управление городским развитием в условиях новых социальных и экономических вызовов пандемии COVID-19. Креативная экономика, 14(7), 1207-1220. doi: 10.18334/ ce.14.7.110674.

9. Sameh Wahba, Jan Vapaavuori. (2020). A functional city's response to the COVID-19 pandemic. 
[Electronic source]. URL: https://blogs.worldbank.org/ sustainablecities/functional-citys-response-covid-19pandemi (date of access 07.09.2020).

10. Квашнина Д.В., Ершова И.Г. (2019). Оценка и развитие инновационного потенциала региона в цифровизации. Вестник Алтайской академии экономики и права, 11, 28-32.

11. Листопад М.Е., Пшул Л.А. (2021) Анализ инвестиционной привлекательности строительной отрасли в современных условиях цифровизации. Вестник НГИЭИ, 3(118), 81-92.

12. Булавко О. А., Татарских Б.Я., Туктарова Л.Р., Наугольнова И. А. (2018). Цифровизация как ключевой фактор повышения инвестиционной привлекательности и инновационного развития промышленных предприятий. Проблемы развития предприятий: теория и практика, 1, 162-168.

13. Методология развития экономики, промышленности и сферы услуг в условиях цифровизации. под ред. д-ра экон. наук, проф. А.В. Бабкина. (2018). Политех-пресс, 756.

14. Alibekova G., Medeni T., Panzabekova A., Mussayeva D. (2020) Digital transformation enablers and barriers in the economy of Kazakhstan. Journal of Asian Finance, Economics and Business, 7(7), 565-575.

15. Panzabekova A., Kireyeva A.A., Satybadin A.A., Sabyr N.S. (2020) Distribution of ICT and Analysis of the Digital Components of the Quality of Life. Journal of Distribution Science, 18(12), 67-77.

16. Жумашева С.Т., Муханова А., Смагулова Ж.Б. (2020) Цифровизация как основа инновационного потенциала аграрного производства Казахстана. Проблемы агрорынка, 2, 45-52.

17. Джуманова Р.А. (2019). Прямые иностранные инвестиции в Республике Казахстан в условиях цифровизации. Инновации, 5(247), 93-99.

18. Нуркатов А.А. (2019). Особенности развития и пространственной дифференциации регионов в условиях цифровизации экономики Республики Казахстан. Вестник Алтайской академии экономики и права, 6, 107-113.

19. Моисеева Т. В. (2020) Оценка влияния развития цифровой экономики на инвестиционный потенциал стран ЕАЭС. Глобальный научный потенциал, 2(107), 150-157.

20. Киселева Е.Г. (2020) Влияние цифровизации на инвестиционный потенциал города. Финансы: теория и практика, 24(5), 72-83.

21. Информационно-аналитическая система «Талдау» Бюро Национальной статистики Агентства по стратегическому планированию и реформам Республики Казахстан [Электронный pecypc]. URL: https://taldau.stat.gov.kz/ru/NewIndex/ GetIndex/2972244?keyword (дата обращения 21.04.2021)

\section{References}

1. Achapovskaja M. (2019). Cifrovizacija jekonomiki kak drajver jekonomicheskogo razvitija. Bankovskij vestnik, 3, 52-58 (In Russ.)

2. Bloomberg J. (2018). Digitization, digitalization, and digital transformation: confuse them at your peri. [Electronic source]. URL: Retrieved on August 28, 2019 from https://www.forbes.com/sites/ jasonbloomberg/2018/04/29/digitization-digitalizationand-digital-transformation-confuse-them-at-yourperil/\#78e677fd2f2c. (date of access 20.05.2021).

3. Parida V., Sjödin D., Reim W. (2019). Reviewing literature on digitalization, business model innovation, and sustainable industry: Past achievements and future promises. Sustainability, 11(2), 18.

4. Brennen J.S., Kreiss D. (2016). Digitalization. The international encyclopedia of communication theory and philosophy, 1-11.

5. Khashimova N., Khusanjanova J. (2016). Generation Of Investment Potential. Voice of Research, $5,1,46-48$

6. Oleinik E., Zakharova A. (2016). Evaluation of the Major Factors of the Region's Investment Activity. Indian Journal of Science and Technology, 9, 36. 1-7.

7. Komarov V.M. Krizis i pandemiya COVID-19 kak okno vozmozhnostey dlya gumanizatsii

gradostroitel'noy politiki. Monitoring of the Economic Situation in Russia, 2020, 8(110), 7-17 (In Russ.)

8. Kurochkin A.V. (2020) Strategic planning and management of urban development in the context of new social and economic challenges of the pandemic COVID-19. Creative Economy, 14(7), 1207-1220. doi: 10.18334/ce.14.7.110674 (in Russ.)

9. Sameh Wahba, Jan Vapaavuori (2020). A functional city's response to the COVID-19 pandemic. [Electronic source]. URL: https://blogs.worldbank.org/ sustainablecities/functional-citys-response-covid-19. pandemi (date of access 07.09.2020).

10. Kvashnina D.V., Ershova I.G. (2019). Ocenka i razvitie innovacionnogo potenciala regiona v cifrovizacii. Vestnik Altajskoj akademii jekonomiki i prava, 11, 28-32.

11. Listopad M.E. Pshul L.A. (2021). Analiz investicionnoj privlekatel'nosti stroitel'noj otrasli v sovremennyh uslovijah cifrovizacii. Vestnik NGIJeI, 3(118), 81-92.

12. Bulavko O. A., Tatarskih B. Ja., Tuktarova L.R., Naugol'nova I.A.(2018). Cifrovizacija kak kljuchevoj faktor povyshenija investicionnoj privlekatel'nosti i innovacionnogo razvitija promyshlennyh predprijatij. Problemy razvitija predprijatij: teorija i praktika, 1, 162-168.

13. Metodologija razvitija jekonomiki, promyshlennosti i sfery uslug $\mathrm{v}$ uslovijah cifrovizacii. pod red. d-ra jekon. nauk, prof. A. V. Babkina (2018). Politeh-press, 756 (in Russ.)

14. Alibekova G., Medeni T., Panzabekova A., Mussayeva D. (2020). Digital transformation enablers and barriers in the economy of Kazakhstan. Journal of Asian Finance, Economics and Business, 7(7), 565-575

15. Panzabekova A., Kireyeva A.A., Satybadin, A.A., Sabyr N.S. (2020). Distribution of ICT and 


\section{ИННОВАЦИИ, ИННОВАЦИОННО-ТЕХНОЛОГИЧЕСКОЕ РАЗВИТИЕ, ЦИФРОВИЗАЦИЯ}

Analysis of the Digital Components of the Quality of Life. Journal of Distribution Science, 18(12), 67-77

16. Zhumasheva S.T., Muhanova A., Smagulova Zh. B. (2020). Cifrovizacija kak osnova innovacionnogo potenciala agrarnogo proizvodstva Kazahstana. Problemy agrorynka, 2, 45-52 (in Russ.)

17. Dzhumanova R.A. (2019). Prjamye inostrannye investicii $\mathrm{V}$ Respublike Kazahstan V uslovijah cifrovizacii. Innovacii, 5(247), 93-99 (in Russ.)

18. Nurkatov A.A. (2019). Osobennosti razvitija i prostranstvennoj differenciacii regionov $\mathrm{v}$ uslovijah cifrovizacii jekonomiki Respubliki Kazahstan. Vestnik Altajskoj akademii jekonomiki i prava, 6, 107113 (in Russ.)
18. Moiseeva T.V. (2020). Ocenka vlijanija razvitija cifrovoj jekonomiki na investicionnyj potencial stran EAJeS. Global'nyj nauchnyj potencial, 2(107), 150-157. (in Russ.)

20. Kiseleva E.G. (2020). Vlijanie cifrovizacii na investicionnyj potencial goroda. Finansy: teorija i praktika, 24(5),72-83(in Russ.)

21. Informacionno-analiticheskaya sistema «Taldau» Byuro Nacional'noj statistiki Agentstva po strategicheskomu planirovaniyu i reformam Respubliki Kazahstan [Electronic source]. URL: https://taldau.stat. gov.kz/ru/NewIndex/GetIndex/2972244?keyword (date of access 21.04.2021)

\section{Information about the authors}

* Lidiya M. Bekenova - - PhD in Economic sciences, Associate Professor, Almaty Academy of Economics and Statistics, Kazakhstan, e-mail: lida.bekenova@bk.ru. ORCID ID: https://orcid.org/0000-0002-0298-6817

Valeriy A. Korvyakov, Doctor of Pedagogical Sciences, Associate Professor, Almaty Academy of Economics and Statistics, Kazakhstan, rector; e-mail: v.korvyakov@rambler.ru. ORCID ID: https://orcid.org/0000-0001-6605-1896

Igor M. Drapkin - Doctor of Economics, Professor, Department of International economics and management, Ural Federal University, Russian Federation, e-mail: i.m.drapkin@mail.ru. ORCID ID: https://orcid.org/0000-0002-59898463

\section{Авторлар туралы мәліметтер}

* Бекенова Лидия Молдабайқызы - корреспондент автор, экономика ғылымдарының кандидаты, доцент, Алматы экономика және статистика академиясы, Қазақстан Республикасы, e-mail: lida.bekenova@bk.ru. ORCID ID: https://orcid.org/0000-0002-0298-6817

Корвяков Валерий Анатольевич - педагогика ғылымдарының докторы, доцент, Алматы экономика және статистика академиясы, Қазақстан Республикасы, ректор, e-mail: v.korvyakov@,rambler.ru,ORCID ID: https:// orcid.org/0000-0001-6605-1896

Драпкин Игорь Михайлович - экономика ғылымдарының докторы, профессор, Халықаралық экономика және менеджмент кафедрасы, Орал федералдық университеті; Ресей Федерациясы, 19; e-mail: i.m.drapkin@, mail.ru. ORCID ID: https://orcid.org/0000-0002-5989-8463

\section{Сведения об авторах}

* Бекенова Лидия Молдабаевна - кандидат экономических наук, ассоциированный профессор, Алматинская академия экономики и статистики, Республика Казахстан, e-mail: lida.bekenova@,bk.ru. ORCID ID: https:// orcid.org/0000-0002-0298-6817

Корвяков Валерий Анатольевич - доктор педагогических наук, ассоциированный профессор, Алматинская академия экономики и статистики, Республика Казахстан, ректор; e-mail: v.korvyakov@,rambler.ru. ORCID ID: https://orcid.org/0000-0001-6605-1896

Драпкин Игорь Михайлович - доктор экономических наук, профессор, кафедра международной экономики и менеджмента, Уральский федеральный университет; Российская Федерация, e-mail: i.m.drapkin@mail.ru. ORCID ID: https://orcid.org/0000-0002-5989-8463 